\title{
EL MITO Y LA HISTORIA CRÍTICA O MAYÁNS CONTRA F. J. DE LA HUERTA
}

\author{
José Antonio Caballero López* \\ Universidad de La Rioja
}

\begin{abstract}
RESUMEN: La antigüedad clásica fue la fuente de la que surgió la mayoría de las hazañas de personajes como Atlas, Gerión, Hércules, Gárgoris, etc. que, gracias al evemerismo, se habían incluido como episodios reales en las historias de España y de otras naciones europeas para demostrar los primitivos antecedentes del país. En el siglo XVIII, diversos ilustrados se propusieron reformar los estudios históricos, desterrar esas fábulas y mitos de las historias y desprestigiar las falsas crónicas que los habían difundido.
\end{abstract}

En esta labor destaca Gregorio Mayáns y Siscar, que dedicó sus mayores esfuerzos a combatir la publicación y difusión de lo que él consideraba la continuación en su siglo de la pseudo-historia de los siglos precedentes. Con su censura de la España Primitiva de Francisco Javier de la Huerta y Vega constituyó un espléndido exponente de la aplicación del método crítico a la práctica de la historiografía.

ABSTRACT: Classical antiquity was the source from which emerged most of the exploits of characters such as Atlas, Geryon, Hercules, Gargoris, etc. that as a result of euhemerism had featured as actual episodes in the histories of Spain and other European nations in order to demonstrate the primitive and prestigious background of the country. In the eighteenth century, several "ilustrados" attempted to reform the historical studies and to banish these fables and myths.

One outstanding exponent of this concern is Gregorio Mayáns, who devoted his utmost efforts combating the publication and dissemination of what he regarded as the continuation of the pseudo-history of preceding centuries. His critique of Francisco Javier de la Huerta y Vega's España Primitiva was a splendid example of the application of a critical method to the practice of historiography.

PALABRAS CLAVE: Mito, historia crítica, Mayáns, Huerta y Vega.

KEYWORDS: Myth, critical history, Mayáns, Huerta y Vega.

* El autor pertenece al Centro de Investigación en Lenguas Aplicadas (CILAP) de la Universidad de La Rioja. 
El siglo XVIII español fue, en gran parte, una centuria de proyectos reformistas que unas veces, las más, fracasaron y otras, las menos, llegaron a convertirse en realidad ${ }^{1}$. Resulta claro, a estas alturas, que la razón del triunfo o el fracaso no hay que buscarla en el mérito o demérito del proyecto en sí, ni en la capacidad del autor que intentó su realización. Una serie de razones contribuyeron al resultado positivo o negativo. Y, por supuesto, no fue la menos importante la actitud de los gobiernos borbónicos a lo largo del siglo (Mestre, Despotismo 107). Como suele ocurrir, no siempre los criterios de gobiernos e intelectuales coinciden. Dicho de otro modo y en relación con el momento histórico que aquí nos interesa: más de una vez los intereses políticos de quienes detentaron el gobierno en el siglo XVIII chocaban con los planteamientos reformistas de los ilustrados.

Y en aquellos impulsos reformistas un área era especialmente sensible: la historiografía crítica y científicamente concebida. No es de extrañar que todos los grandes ilustrados del siglo XVIII emprendieran trabajos de historia, entre ellos Manuel Martí, Pedro Rodríguez Campomanes, Benito Feijoo, Gregorio Mayáns, Enrique Flórez, Andrés Marcos Burriel, Gaspar Melchor de Jovellanos. Y todos ellos, aunque desde circunstancias personales bien distintas, estaban inmersos en una batalla que adquirió, en muchos casos, caracteres dramáticos.

Era la pugna entre mito -tradición- documento fehaciente. Porque frente al mito, apoyado por el exagerado nacionalismo y la superstición, se presenta la ciencia histórica, basada en unos métodos rigurosos que exigen pruebas concluyentes. Pero pocos historiadores llevaron el espíritu crítico hasta sus últimas consecuencias. Había para esa limitación una razón potentísima: las implicaciones político-sociales de lo que se quería desechar de las historias anteriores. Feijoo es un buen reflejo de esas limitaciones. Con toda su valentía, no se atrevió a enfrentarse con sentido crítico a los mitos nacionales. En propias palabras:

\footnotetext{
Mas, cuando no hay argumento positivo contra las tradiciones, sí sólo el negativo de la falta de monumentos que las califique... no (hay que) turbar al pueblo en su posesión, ya porque tiene derecho a ella, siempre que no puede apurarse la verdad, ya que de mover la cuestión no puede acogerse otro fruto que disensiones en la república literaria y dicterios contra el que emprendió la guerra. Cuando yo, por más tortura que dé al discurso, no pueda pasar de una prudente duda, me la guardaré depositada en la mente y dejaré al pueblo en todas aquellas opiniones que, o entretienen su vanidad, o fomentan su devoción (Teatro Crítico IV, XIII, XX, 74-75).
}

1. Este trabajo se enmarca dentro del proyecto "Enciclopedia de la retórica española del siglo XVII" (Ministerio de Ciencia e Innovación, FFI2008-03246/FILO, 2009-2011). Dejamos constancia de nuestro agradecimiento. 
Es necesario tener presente esta situación cultural de la España del XVIII para comprender el alcance de la obra de Feijoo o la de otros ilustrados (Álvarez Barrientos y Mestre Sanchís 61).

Las primeras y esplendorosas manifestaciones de esta crítica histórica surgieron en España a fines del siglo XVII y partieron, sobre todo, de Nicolás Antonio, del Marqués de Mondéjar y de Juan Lucas Cortés. Sus fundamentos los constituían la necesidad de editar las fuentes históricas y el criticismo de método y planteamiento. Y esa será la herencia cultural del barroco para la generación de ilustrados que se propuso en el XVIII la reforma de los estudios históricos.

La publicación de las fuentes y documentos originales será presentada, por un lado, como condición necesaria para lograr una historiografía responsable. Además, había que editar las obras históricas escritas con rigor para que sirvieran de modelo metodológico. El objetivo básico era acabar con las fabulaciones y mitos que las falsas historias habían introducido en la credulidad de la gente e incluso contaminado a bastantes historiadores.

¿Cuáles son esos mitos que ya habían conformado el imaginario patrio y que tanto costaba desterrar de las mentes crédulas de muchos españoles? Hemos de retrotraernos unos cuantos siglos en el tiempo para valorar convenientemente el enorme esfuerzo que tuvieron que realizar quienes en el siglo XVIII se propusieron, incluso a costa de su propia carrera política y académica, encontrar la verdad de nuestro pasado y superar la ignorancia y la credulidad.

En efecto, la historiografía clásica, no sin dificultad, había llegado a distinguir entre mito e historia (Caballero, "Desde el mito" 36). Y así, en la conocida formulación de Varrón, citado por Censorino en su De die natali ${ }^{2}$, se señalaba un período anterior al primer cataclismo, sobre el que todo era desconocido, de donde el nombre de ádelon "obscuro"; una época anterior a la primera olimpiada, a la que se calificaba como "mítica"; y la época posterior a la primera olimpiada (776 a.J.C.), a la que se llamaba propiamente "histórica", porque los relatos que de ella se poseían eran ya veraces.

La cronografía cristiana, en cambio, rompió, de nuevo, con la división entre mito e historia. Con el cristianismo todo es ya historia; pues, al atribuir la cate-

2. 21, 1, ed. O. Jahn, 1965: Hic [...] tria discrimina temporum esse tradit: primum ab hominum principio ad cathaclismum priorem, quod propter ignorantiam vocatur adelon, secundum a cathaclismo priore ad olympiadem primam, quod, quia multa in eo fabulosa referuntur, mythicon appellatur, tertium a prima olympiade ad nos, quod dicitur historicon, quia res in eo gestae veris historiis continentur ... 
goría de vera historia a la Biblia, que comienza desde la mismísima Creación, no se deja lugar alguno para el mito (Codoñer 126-127). Lo único que el historiador cristiano consideraba mítico eran ciertos relatos fabulosos de los paganos. Pero incluso esa opinión desapareció cuando se extendió entre los cristianos la doctrina del filósofo Evémero de Mesina, que dejaba reducido el Panteón de la mitología clásica a un cortejo de héroes, sabios y soberanos eminentes divinizados por la admiración popular ${ }^{3}$. Convertidos por ese procedimiento en mortales, se aseguraba la inanidad del paganismo, ya que no significaban competencia alguna para el verus Deus ${ }^{4}$. Pero es durante el siglo VII, en las Etimologías de Isidoro de Sevilla, cuando la aplicación del evemerismo a la historia alcanza su más interesante testimonio. San Isidoro, aceptando el principio evemerista, busca y encuentra en la mitología clásica héroes civilizadores y benefactores de la humanidad (destructores de monstruos, fundadores de ciudades, inventores de las artes) y los sitúa en el mismo nivel, a veces incluso en el mismo linaje, que los personajes de la Historia Sagrada (patriarcas, jueces, profetas).

No es de extrañar, en consecuencia, que tras el hispalense no haya cronista que omita la inserción en sus historias universales de dioses y héroes míticos humanizados (Seznec 21-22). Además, la propia inclusión del mito, por su prestigio y valor paradigmático, permitía ampliar y encarecer el fondo de antigüedad y, por ende, mejorar la ejecutoria de nobleza del país o reino que se historiaba.

Ese fue el principal vehículo de reintroducción de los mitos en la historiografía. Los personajes de la mitología se convierten en los progenitores, epónimos y gobernantes gloriosos de una nación. En lo que a España se refiere, hemos de esperar a Jiménez de Rada, en el siglo XIII, para encontrar la primera formulación coherente de nuestro pasado mítico (Caballero, "El mito" 84). Veamos cuáles son sus claves fundamentales.

\footnotetext{
3. Evémero de Mesina (330-250 a.J.C.) afirma que los dioses, cuando no representaban las fuerzas de la naturaleza, eran en origen sólo hombres, que por sus cualidades excepcionales habían conquistado la veneración de sus súbditos. Evémero escribió en griego un libro titulado Anagraphè hierá en el que expone en forma alegórica su interpretación racionalista de la religión griega. El libro habla de un hipotético viaje y de una ciudad ideal: Panquea, situada en una isla del Océano, en la que había una estela de oro que narraba las gestas de Urano, Crono y Zeus. Sobre la base de este "testimonio", Evémero explica una teoría llamada a ejercer una enorme influencia. A su difusión contribuiría enormemente Diodoro Sículo, que aplica el evemerismo en su Biblioteca Histórica.

4. La mejor guía sobre el origen y transcendencia del evemerismo sigue hallándose en J. Seznec, Los Dioses de la Antigüedad, Madrid, 1983. Puede verse también D. Cameron Allen, Mysteriously Meant. The Rediscovery of Pagan Symbolism and Allegorical Interpretation in the Renaissance, Baltimore, 1970.
} 
Para un cristiano, el más antiguo de los orígenes de cualquier pueblo no podía retrotraerse más allá del Diluvio y de Noé. Por ello, la destrucción de Troya o la fundación de Roma, con que daban comienzo la historias universales de griegos y romanos respectivamente, se sustituyen ahora por la Creación y el Diluvio, como ya hicieran Eusebio $^{5}$ y, a partir de él, San Jerónimo y San Isidoro.

A su vez, una noticia procedente de las Antigüedades Judaicas de Flavio Josefo $(I, 6,1)$ refería que Túbal, hijo de Jafet, uno de los descendientes de Noé, había llegado a Hispania. Josefo reproduciría en ella el saber admitido como válido por los judíos de su época (Lida de Malkiel 12-13), ya que, como Hispania era en la Antigüedad la tierra de los metales por excelencia ${ }^{6}$, los rabinos le asignaron por poblador a aquel entre los patriarcas que había creado el arte de la forja. Obró la semejanza de nombre entre Túbal hijo de Jafet y el hijo de Lamec, Túbal-Caín, de quien el Génesis (IX, 22) dice que fue "acicalador de toda obra de metal y de hierro". La información de Josefo adquiere especial predicamento dentro de España y a su difusión y vigencia contribuye la "enciclopedia" isidoriana, que la incluye sin discutirla?.

Y, en efecto, Jiménez de Rada escribe en su Historia de rebus Hispaniae que Túbal fue, tras el Diluvio, el primer poblador de la Península, para lo que aduce el correspondiente argumento etimológico, pues el antiguo gentilicio Cetubales quiere decir "grey de Túbal" (coetus Tubal) y sólo después de su asentamiento a orillas del Ebro (Hiberus), habrían cambiado su nombre por el de Celtiberes. Luego, la "grey de Túbal" se extendió por toda la Península, que llamaron Hesperia por la estrella Héspero que divisaban siempre en el horizonte, y en las distintas provincias tuvieron distintos jefes, uno de los cuales fue Gerión. Al mítico pastor se le llama, como era tradicional ${ }^{8}$, Geryon Triceps y, en interpretación evemerista, se le convierte en gobernante, en virtud de su nombre, de tres reinos: Galicia, Lusitania y Bética.

Gerión sirve de engarce para la introducción de la saga de Hércules, de manera que la historia de España quedaba ligada no sólo a los orígenes bíblicos, sino

5. Eusebio, incidiendo en un camino frecuentado por los primeros apologistas, aspira a demostrar que la cultura judía es más antigua que cualquier otra y que, por lo mismo, la ejecutoria de nobleza del cristianismo es también mucho más ilustre.

6. Cf. Estrabón, Geografía, III, 2, 8: "Pero, a pesar de estar dotada dicha región de tantos bienes, no se maravillaría uno menos, sino todo lo contrario, al conocer la generosidad de sus minas; porque de ellas está repleta toda la tierra de los iberos". Y Covarrubias, s.v. "España": "Antiguamente España devió ser para las otras naciones lo que agora las Indias para nosotros, como consta de muchos autores...".

7. San Isidoro, Etym., IX 2, 29: Thubal, a quo Iberi, qui et Hispani; licet quidam ex eo et Italos suspicentur.

8. Él mismo cita aquí un testimonio de las Metamorfosis y otro de las Heroidas de Ovidio. 
también al mundo clásico. La literatura grecolatina había referido, ciertamente, numerosas conexiones de Hércules con el extremo occidental de Europa, localizando en esta zona geográfica la isla mítica de Eritía, residencia del pastor Gerión, las columnas de Hércules y el jardín de las Hespérides ${ }^{9}$. Pero en esta historia primitiva de España, en lo que parece un afán por poner de relieve la presencia del héroe clásico en la Península, sus gestas se utilizan para explicar la etimología de numerosos topónimos peninsulares, ya que Hércules habría recorrido toda la Península fundando ciudades al ritmo de sus conquistas ${ }^{10}$. Así se explican Galicia (de Galatae, tribu que había venido con él desde Galacia), Lusitania (de lusus Liberi y Ana; referencia a los juegos que instituyó cerca del río Ana -Guadiana- en honor de Liber Pater), Híspalis (porque fue poblada por la tribu de los Espalos que iban con él o porque construyeron sus primeros habitáculos sobre palos ${ }^{11}$ ), Tarazona (o Tirasona, de Tyrii y Ausonii, otras dos tribus que acompañaron al héroe en su viaje por la Península), ciudad que edificaron en las faldas del Moncayo o Mons Caci, para perpetuar la victoria de Hércules sobre Caco); Urgel (porque "urgía" con la guerra a sus habitantes), Barcelona (Barchinona, porque Hércules, tras dejar ocho naves en Galicia de las nueve que trajo, atracó con la barcha nona en ese lugar), etc.: toda una lección de sincretismo interesado.

Tras la saga de Hércules, viene la de Hispán, trasunto del mítico Yolao. Se le hace el noble compañero de Hércules a quien el héroe, después de haber subyugado toda la Península, confía las riendas del gobierno y por cuyo nombre fue llamada Hispania en lugar de Hesperia ${ }^{12}$. He aquí ya nuestro héroe epónimo y el primer

9. Lucas de Tuy, siguiendo las crónicas visigóticas, se había limitado en su Chronicon Mundi a mencionar unos cuantos episodios desconectados referentes a la derrota del gigante Anteo en Libia, a la destrucción de Troya y a la muerte sobre una pira del héroe desesperado por el ardor de la túnica de Deyanira. Esto se recoge, seguramente como concesión y a modo de digresión, en el cap. VI de la Historia de rebus Hispaniae. Sobre las fuentes e interpretación histórico-cultural de los mitos relacionados con Hércules en Occidente, cf. R. C. Knapp, "La via heraclea en Occidente: mito, arqueología, propaganda, historia”, Emerita 54, 1986, pp. 103-122.

10. J.A. Estévez Sola (“Aproximación” 144-5) observa cómo el Toledano ajusta a este propósito, cambiando el nombre de Alejandro por el de Hércules, un texto de Paulo Orosio referido a las conquistas del macedonio. Alejandro, como luego Augusto, fue equiparado en la Antigüedad a Hércules.

11. Es la etimología de San Isidoro (XV, 1, 71): Hispalim autem a situ cognominata est, eo quod in solo palustri suffixis in profundo palis locata sit, ne lubrico atque instabili fundamento cederet.

12. San Isidoro (XIV 4, 29) hacía proceder Hispania de Híspalo: Hispania prius ab Ibero amne Iberia nuncupata, postea ab Hispalo Hispania cognominata est. Ipsa est et vera Hesperia ab Hespero stella occidentali dicta. Lucas de Tuy, en la loa de Hispania incluida en su Chronicon, daba una etimología griega: is "uno", pan "todo", ia (?) "estrella"; es decir, "sola toda estrella". En el Epítome de las Historias Filípicas de Pompeyo Trogo realizado por Justino en el siglo II-III, en el capítulo XLIV, que se ocupa monográficamente de Hispania, ya se leía: Hanc ueteres ab Hibero amne primum Hiberiam, postea ab Hispalo Hispaniam congnominaverunt. (1.2). 
"gobernante" de una España más o menos pacificada y unificada. Cronológicamente -señalaba Jiménez de Rada- estamos en el tiempo en que Alejandro raptó a Helena y estalló la guerra de Troya (I, 6, 45-6). Tan antiguo sería este Hispán, entre cuyas gestas se cuentan nada menos que la fundación de Segovia (que vendría de secus Cobiam "junto a Cobia"), la construcción de su acueducto y la edificación de las famosas "torres en Galicia y en Gades", tradicionalmente atribuida a Hércules.

La leyenda de Hércules, evidentemente, constituía un basamento firme para la etnología clásica de la monarquía española, la principal promotora de las empresas historiográficas (Tate 18). La aparición del gobernante epónimo Hispán, aunque tarde, sería paralela a la creación de Franco, hijo de Eneas y fundador de la dinastía francesa en la Crónica de Fredegario (siglo VII), y de Brito, hijo de Silvio de la estirpe de Eneas, en la Historia regum Britanniae de Godofredo de Monmouth. Su propósito no era otro que proveer a la población española de antigüedad constatable y de raigambre legendaria, habida cuenta de la importancia que se daba a la antigüedad en la reclamación de los derechos de conquista o de prelación.

Alfonso X “el sabio”, en su Primera Crónica General, además de dar mayor importancia (cifrada en la extensión del espacio que les dedica) a las hazañas del héroe clásico que a las del bíblico, introduce una notable innovación: Hispán es el primer "sennor" de España. Pero ahora no es compañero, sino sobrino de Hércules. Se crea de esta manera un lazo de consanguineidad con el héroe, porque el imperium, motivo que preside - no hay que olvidarlo- las Estorias de Alfonso (Fernández Ordóñez passim), sólo se transmite por linaje.

Con Rodrigo Sánchez de Arévalo y su Compendiosa Historia Hispanica (publicada en 1470) las hazañas de Hércules en la Península, hasta ahora núcleo básico de su pasado mítico, pierden importancia, pero aumenta la nómina de reyes fabulosos. Ya había a mano otras fuentes antiguas y Sánchez de Arévalo, interpretando a Justino (XLIV 4, 1-14), cita como reyes de España que antecedieron a Hércules a Teucro, hijo de Telamón y hermano de Áyax, fundador de Teucria o Cartago Nova; al tartesio Gárgoris y a su sucesor Habis; a Caco y a Gerión Triceps, rey de Andalucía, Extremadura y Galicia.

Se percibe, pues, una progresiva disminución del espacio dedicado al pasado mítico que se ve compensada con la inclusión de nuevos personajes legendarios al panteón real motivado por el acceso a otras fuentes. Mas, en esa línea, la elaboración más inspirada y original para el período primitivo de la Península no llegará hasta la publicación a finales del siglo XV de los Commentaria de Annio de Viterbo, el falso Beroso, gran e influyente fabulador de los precedentes míticos de España y de su monarquía (Caballero, "El Beroso" 116 ss.). 
Este inteligente dominico, llamado Giovanni Nanni, que había latinizado su nombre en Annius Viterbensis, según el prurito humanista, inventa los propios fragmentos de autores antiguos que le sirven de apoyatura para el relato de los primeros tiempos de España y de sus primeros reyes. A ellos les dedica un libro que titula De primis temporibus et quatuor ac viginti regibus Hispaniae et ejus antiquitate, una especie de prontuario que se añade a algunas ediciones de su obra magna: los Commentaria super opera auctorum diversorum de antiquitatibus loquentium. La obra se publicó por primera vez en Roma, en $1498^{13}$, y aparece dedicada, oportunamente, a los Reyes Católicos, testigo como era el Viterbense de la cada vez mayor influencia española en la política italiana.

Tuvo una aceptación inmensa tanto en España como fuera, a juzgar por el número de sus traducciones y reediciones, de las cuales la más divulgada fue la de Amberes de $1552^{14}$. En ella aparece ya el nombre de Beroso destacado en el título, porque es este autor con sus apócrifos textos quien da las claves para obtener una visión completa de la historia primitiva del mundo y de cada una de las naciones que se citan desde sus orígenes, razón por la que a Annio se le conoce más como Beroso o el falso Beroso (Caro Baroja, Las falsificaciones 68).

En efecto, basándose en el supuesto testimonio del caldeo Beroso ${ }^{15}$ y en los de otros autores antiguos inventados o interpretados sagazmente, daba a los españoles prioridad sobre los griegos y romanos en el dominio cultural e histórico; en lo cultural, porque los hispanos conocieron la escritura y tuvieron filosofía y leyes mucho antes que los griegos ${ }^{16}$. En lo histórico, porque la lista de sus reyes arranca 143 años después del Diluvio y 637 años antes de la fundación de Troya.

13. La edición moderna, con traducción y comentario, la estamos realizando en el marco de un proyecto de investigación en la Universidad de La Rioja.

14. Berosi sacerdotis Chaldaici, Antiquitatum Italiae ac totius orbis libris quinque, Commentariis Ioannis Annii Viterbensis, Antverpiae, in aedibus Ioan. Steelsii, 1552. En ella el libro De primis temporibus et quatuor ac viginti regibus Hispaniae et ejus antiquitate ocupa el último lugar, como si de un añadido-resumen sobre la antigüedad de España se tratase.

15. Los fragmentos que se conservan del auténtico Beroso (siglo III a. C.) fueron editados por F. Jacoby en Die Fragmente der Griechischen Historiker, 11l C, Leiden, 1958, pp. 364-397. Escribió en griego una obra histórica titulada Babiloniaká, dedicada a Antíoco III. Los fragmentos que conservamos son, fundamentalmente, los resúmenes y citas que de ella hacen Flavio Josefo y Eusebio de Cesárea sobre la Creación, los diez reyes anteriores al Diluvio, el Diluvio mismo, el arca de Noé y la restauración posterior de la realeza, con otra larga lista de reyes hasta la tardía historia de Asiria, Babilonia y Persia. Beroso, aun apoyándose en fuentes y documentos que se han confirmado como exactos, definió un ciclo histórico fabuloso de 36.000 años; es decir, y de ahí su autoridad, que abarcó lo más antiguo que cabía imaginar en la Antigüedad.

16. De primis temporibus... Cap. II: Hispaniae quam Graeciae antiquior est splendor et philosophia (f. 290v de la ed. de Amberes). Cf. también en los Commmentaria al libro V de Beroso (f. 36v): Quare phi- 
Con el falso Beroso se eleva a veinticuatro la serie de reyes fabulosos encabezados, como es tradicional, por Túbal, el primer rey de Hispania y quien dio leyes a los hispanos y les enseñó las letras, la poesía y la filosofía moral. Pero lo más importante es que se consolida el método tan evemerista de descubrir reyes antiguos a partir de ríos, montes, ciudades y étnicos, cuyos nombres guardarían el recuerdo de héroes y personajes reales (Pérez Vilatela 808 y 812). Así, deriva de ríos los nombres de los reyes Iberus (sucesor e hijo de Túbal), Tagus, Betus y Sycoris; Brigus lo saca del elemento toponímico -briga, tan abundante en España; con Valencia relaciona al rey Romus, por correspondencia semántica entre el latino valentia y el griego rhóme. De étnicos peninsulares o extra-peninsulares, pero relacionados con ámbitos de influencia de la monarquía de los Reyes Católicos, deriva los nombres de los reyes Lusus, Italus, Sicanus, Siceleus y Siculus, y así sucesivamente. Hércules, por supuesto, sigue teniendo su lugar en el panteón real y durante su reinado funda las ciudades acostumbradas y alguna más: Iulia Libica (Llivia) y Herculea Cervalaria (en la Cerdaña), alusión evidente a la españolidad del Rosellón y la Cerdaña (Pérez Vilatela 811). Y, de paso, resuelve las críticas que en contra del héroe clásico y de sus andanzas "españolas" se habían formulado por algunos historiadores ${ }^{17}$ dándole el gentilicio de Lybicus. La lista la cierran los reyes Cacus, Erythrus y Mellicola. Cacus habría sido un joven celtíbero, el primero en utilizar armas de hierro (vestigios de su mítica caracterización como hijo de Vulcano). El segundo saca su nombre de la isla Erythra, "la roja", situada frente a Gades: en esto ha venido a parar la Eritía (Erytheía) de las fuentes clásicas, la isla de Gerión y el lugar donde Hércules le robó el ganado y le dio muerte. Es a propósito de este rey Erythrus que Annio cita el bandidaje y piratería del Hércules Griego o Hercules Alceus. Mellicola, por fin, es el tradicional Gárgoris, que fue el primero en enseñar a los hispanos la recolección de la miel: de ahí su nombre. A Habis lo cita de pasada, como heredero de la fortuna de su abuelo Gárgoris. Pero Annio, que sin duda conocía su incestuosa procedencia, no le otorga la condición de rey.

Nos encontramos, según su cronología comparada, en el primer año después de la destrucción de Troya, a 1131 años del diluvio, a 988 de la fundación de His-

\footnotetext{
losophia et literae non minus septingentis annis fuere ante Hispanis quam Graecis. Initium ergo Philosophiae a Barbaris non a Graecis fuerit. Quadrant autem traditiones Hispanorum, et Berosi dicentis, quod Tubal Samothes, et Tuyscon anno quarto Nini formant legibus sua regna. Et ut ait Strabo, circa Beticam doctiores Hispani ea tempora tradunt. Pero el polivalente Viterbense también sería utilizado en otras naciones europeas con ese mismo propósito de otorgarse la primacía cultural e histórica. Cf. R.E. Asher, "Berosus", en National Myths in Renaissance France: Francus, Samothes and the Druids, Edimburgh, 1993, cap. II.

17. Véase, por ejemplo, Joan Margarit y Pau, que en su Paralipomenon Hispaniae, p. 20, escribe: Non ergo quisquam putet hunc Herculem nostrum illum esse qui illa XXI [sic] pericula superavit. Hic enim noster sceleratissimus et omnium sui nominis deterrimus fuit.
} 
pania, 131 años antes de la fundación de Roma y 1188 años antes del nacimiento de Jesucristo. Mediante la inteligente manipulación del mito, queda probado el antiquísimo y glorioso origen de España. De paso, se supera el despectivo juicio de aquellos humanistas italianos que hacían proceder a los españoles de los incultos godos, los destructores del Imperio Romano ${ }^{18}$ :

Los godos posteriores no alteraron -concluye Annio- el venerable origen del pueblo de España. Este es, pues, excelsos reyes Fernando e Isabel, cristianísimos príncipes, vuestro verdadero origen, $\tan$ grande como inalterado ${ }^{19}$.

Las fabulaciones de Annio de Viterbo ejercieron una considerable influencia sobre los historiadores posteriores, que incluso, una vez aprendido el método, las revisaron y aumentaron al socaire de sus propios intereses. El más conocido de sus continuadores es Florián de Ocampo, cronista real de Carlos I, que en 1543 publicó en Zamora su Crónica general de España. En ella, a pesar de las reservas que en ocasiones manifiesta ${ }^{20}$, reproduce y detalla con habilidad los apócrifos del Viterbense, consagrando un largo capítulo a cada uno de sus reyes fabulosos, incluido Habis ${ }^{21}$.

La bola de nieve se había echado a andar y en el siglo XVII Gregorio Argaiz, en su enorme Población eclesiástica de España, no tiene empacho en nombrar nada menos que a Adán y Eva primeros reyes de España y muestra un afán desenfrenado por atribuir fundaciones de ciudades a este o aquel rey, aparte de hacer a Homero español por parte de madre. A pesar de los esfuerzos críticos de Nicolás Antonio, del marqués Mondéjar y algunos otros, la aparición de historias fabulosas basadas en documentos falsos no se detendría.

Con estos antecedentes, es comprensible que quienes en el siglo XVIII tomaron sobre sus espaldas la tarea de reformar los estudios históricos con método crítico lucharan con todas sus fuerzas para evitar la difusión de los mitos y las falsedades de la historia de España.

18. Tate 93: "A partir de Petrarca y Boccaccio los eruditos habían expuesto la idea de que los godos fueron los responsables de la destrucción del Imperio Romano, iniciando a continuación un reinado de oscuridad cultural que había comenzado a desaparecer únicamente en el tiempo presente".

19. F. 291r: Posteri Gothi non variaverint priscam originem Hispanicae gentis. Haec igitur est tum invariata, tum maxime vera vestra origo celsi reges Ferdinande et Helisabet christianissimi principes.

20. Cap. IV: "Bien es verdad que según las sospechas que muchos platican de este Juan de Viterbo y de su Beroso, yo quisiera tener de tiempos tan antiguos algún autor de menos inconvenientes...". Véase Caro Baroja, Las falsificaiones 84-104.

21. Sobre los numerosos falsarios que se compusieron a la lumbre de Annio de Viterbo, véase Godoy Alcántara, Historia y Caro Baroja, Las falsificaiones. 
En esta labor destaca la figura y la obra de Gregorio Mayáns y Siscar. Los obstáculos que encontró, las persecuciones que sufrió, su éxito europeo y su relativo fracaso en España son conocidos ${ }^{22}$. Además, sus ideas y sus obras fueron paradigma y acicate para los historiadores posteriores. Enrique Flórez con su España Sagrada y su Clave Historial, Juan Forner con su Discurso sobre el medio de escribir y mejorar la historia de España, o Andrés Marcos Burriel con sus trabajos de investigación en los archivos eclesiásticos, y otros continuaron, dentro de sus propios criterios, el reformismo histórico y el método crítico del escritor valenciano.

Mayáns, en efecto, pondrá su mayor empeño por conseguir desterrar las fábulas y mitos de las historias y por desprestigiar las falsas crónicas que los habían difundido. En su Oración de alabanza de las obras de D. Diego Saavedra Fajardo (1725) critica, por ejemplo, a los autores que los aceptaron con credulidad. Él fue también el editor en el siglo XVIII, tras afanosa búsqueda de los originales, de la Censura de historias fabulosas de Nicolás Antonio, la obra que, para él, había marcado un hito en el siglo anterior en la conformación de la crítica histórica.

Pero sus mayores esfuerzos en este campo los dedicó a combatir la publicación y difusión de lo que él consideraba la continuación en su siglo de la pseudohistoria de los siglos precedentes. Ciertamente, su censura de la España Primiti$v a$ de Francisco Javier de la Huerta y Vega constituyó un espléndido exponente de la aplicación del método crítico a la práctica de los estudios históricos.

El enemigo a batir no era fácil, pues De la Huerta y Vega no era un simple continuador en el siglo de las luces de aquellos mitos patrios que otorgaban a España el privilegio de la noble descendencia y el prestigio de la antigüedad. En su condición de académico de las Reales Academias de la Historia y de la Lengua, había logrado el beneplácito de las doctas instituciones para la publicación en 1738 de La España Primitiva, cuyo subtítulo reza Historia de sus reyes y monarcas, desde su población hasta Christo.

Este "escritor novelero, poseído de falso patriotismo", en palabras de Godoy Alcántara (305), pretende ampliar a 66 el número de los reyes primigenios de las Españas, muchos de ellos, afirma, injustamente olvidados por las historias. En la más pura tradición evemerista, sus nombres se van ideando a partir de la Biblia, de la mitología y de crónicas e historias apócrifas anteriores.

22. Ha sido Antonio Mestre quien mayores esfuerzos ha dedicado a destacar la importancia de la obra de Mayáns en el reformismo español. 
Ahora el primer rey de España es Tharsis, nieto de Jafet (hijo mayor de Noé), que reinó durante 105 años. Túbal había sido desposeído de tal privilegio por culpa de las críticas que había recibido el falso Beroso y sus continuadores. A Tharsis le sucederá su hijo Héber, una burda paronomosia del nombre del río Ebro. No hay que olvidar que en aquellas historias los "cetúbales", el gentilicio que significaba "grey de Túbal", habían cambiado pronto su nombre por el de "celtíberes". Y eso es lo que subyace en el nombre de este rey, a parte de que, como se verá luego, el verdadero autor de la crónica en la que se basaba De la Huerta era el zaragozano José Pellicer. A este rey da también los nombres de Evenor y Eumelo, con evidentes reminiscencias clásicas. Eumelo, incluso, se identifica con el imaginario rey de la Atlántida de Platón, tantas veces localizada por estos pagos. El tercero de los reyes también recibe tres nombres: Bósforo, Neptuno e Hipio. Le sucede su segundo hijo, de nombre Gadírico o Eumelo (otra vez el mítico rey de la Atlántida en relación ahora con la Gadir del propio mito), que reinó cien años. Y tras el cuarto de los reyes, Bebrice, viene Hércules a quien casa con Pirene, hija de Bebrice. Así que Hércules se convierte en rey consorte. Y ahora vienen, pero ordenados de distinta manera, los nombres heredados de la tradición historiográfica anterior: Horos, a quien se hace hijo mayor de Hércules; Hiperión, Atlante, hermano del anterior, Héspero, su hijo, y Pana (el antiguo Hispán), hermano de Atlante, de quien España tomó su nombre. Han transcurrido en reinado ininterrumpido 491 años. Y así va pergeñando una lista que pretendía llevar sin solución de continuidad hasta el año 44 de la era con Filócoro, durante cuyo reinado, ¡oh maravilla!, llegaría a España el apóstol Santiago en cuerpo y alma a predicar la buena nueva, conectando su historia con otra piadosa tradición patria.

Pero es mejor ceder la palabra al propio Francisco Javier de la Huerta que cifra de la siguiente manera su despropósito:

Se verá continuada la monarquía de España por dilatada serie de monarcas que dieron pobladores a la Inglaterra, Escocia e Irlanda, i aun a la América, i embiaron colonias que dieron nombre a la Iberia oriental. Que poseyeron debajo de su dominio toda la Libia en la África: que dieron reyes a los celtas hoi franceses; que fueron branca suya los reyes de la decantada Troya. Igualmente se hará demostración de aver los españoles ocupado por muchos años a Sicilia, i lo que es más, poblado, i fundado la gran ciudad de Roma cabeza del mundo, siendo fábula conocida que de Eneas procediesen los reyes de Alba, progenitores que se dicen de Rómulo i Remo. Últimamente se hará evidente demostración que toda la fábula i mithología gentilicia tuvo su fuente i origen en principes verdaderos españoles; de suerte que casi todos quantos como dioses veneró la idolatría del mundo antiguo fueron, destegido el velo de sus míthicas narraciones, monarcas españoles que ocuparon el trono de las Españas, o hijos o nietos suyos que fundaron con sus líneas nuevas monarquías. De los quales principios se colige la proposición de que España en los dos tiempos 
adelón i míthico fue la cabeza i señora de todo el Occidente, extendiendo su imperio en la Europa por las Galias, Italia, Alemania, Inglaterra e Irlanda, i en la Africa por las Mauritanias que tocaban parte del Mediterráneo i el Occéano hasta el reino de Congo, i la Libia antigua que corría hasta el Egipto, ocupando muchos de los desiertos africanos, i en la América todo su vasto dilatado país de Sur a Norte. Esto fue España en sus principios: todos estos dilatados países la deven o su población, o su gobierno, o sus primeros reyes; i la prueva de todo ello es el asunto de esta obra, que, aunque toda parezca imposible de demostrarse, como obra inédita; pero esperamos suspenda el letor su juicio, hasta registrar sus pruebas ${ }^{23}$.

Son palabras de todo un académico de la Historia a mediados del siglo XVIII. Y, obviamente, las pruebas aludidas no satisficieron a Mayáns, que, con finísima ironía, sentencia en su Censura de España Primitiva:

¡Dichosa España! que logra una historia tan clara de los tiempos obscuros, i una serie de reyes no interrumpida desde el año 525 después del diluvio hasta el 40 de Jesu-Christo, no siendo dificultoso continuarla después acá ${ }^{4}$.

La obra debía tener seis volúmenes, pero sólo aparecieron los dos primeros: afortunadamente, en el parecer de Mayáns, que, justo un año después, escribió su aludida Censura de España Primitiva, a petición del Consejo de Castilla. Fueron tales las mentiras y absurdos que desveló en dicha obra, que Mayáns sufrió las presiones de las Reales Academias para que retirara la censura y, a pesar de su negativa, el Consejo de Castilla permitió la circulación del libro de De la Huerta.

Y, evidentemente, según los presupuestos de la historia crítica, lo primero que se puso a demostrar fue la falsedad de los propios documentos en los que se basó De la Huerta. Asegura el autor de la España Primitiva:

Uno entre todos es particularmente útil, del qual me sirvo con mayor frecuencia en este primer tomo, que es el Chronicón de Pedro Orador de Zaragoza. El qual en concluyendo la obra publicaré para honra de España ${ }^{25}$.

Y Mayáns descubre que el tal Chronicón no es ni del siglo IV, como pretendía De la Huerta, ni de Pedro el Orador; sino fábrica del polígrafo aragonés José Pellicer, cuya desbordante imaginación lo dio a luz en el siglo XVII junto a otros falsos anales e historias fabulosas de reyes de España. Ha reconocido, incluso, la

23. Es transcripción de A. Mestre en Mayáns y Siscar, G., Obras Completas I: Historia, ed. de A. Mestre, Valencia, 1983, p. 270-271.

24. Mayáns y Siscar, G., Obras Completas I: Historia, ed. de A. Mestre, Valencia, 1983, p. 271.

25. Es transcripción de A. Mestre en Mayáns y Siscar, G., Obras Completas I: Historia, ed. de A. Mestre, Valencia, 1983, p. 275. 
letra del propio José Pellicer, en el original del pretendido Chronicón de Pedro Cesaraugustano que Mayáns pudo ver en la Biblioteca Real.

Es mui natural" -escribe Mayáns- "que el que hace una obra dege en ella señas, o voluntarias de su persona, o involuntarias del carácter de su genio .... Assí también el fabricador del Chronicón del falso Pedro no supo disimular que era aragonés, i natural de Zaragoza, porque empezando por las glorias de su patria Zaragoza en el año de la creación del mundo 2890, según la computación hebrea, escrivió assí: Heber anno octavo regni sui civitatem extruxit juxta flumen magnum, quem (assí dice con solecismo) Eridanum dixit (Vea V.A. cómo se hablava griego en tiempo de Heber hijo de Tharsis, i como el Eridano, hoy el Po, es el Hebro, según Plinio, por haber entendido mal al trágico Esquilo): Posteaque Hiberus nominatus est, Civitati autem nomen imposuit Herbim a filiae nomine, quae a Salduba (Príncipe imaginario sacado del nombre antiguo de Zaragoza) reaedificata, nomen suum retinuit usque ad Augusti tempora, qui eam ornavit, et decoravit, et Caesaraugustam vocavit. Esto dice que pasó el año 2090 antes de Jesu Christo ${ }^{26}$.

Al falsario autor del cronicón se le nota también su querencia aragonesa cuando inventa un rey llamado justamente Arrhagonio, el número 39 de la lista, nieto de Oscho y casado con una tal Jacha (nombres ambos relacionados evidentemente con los topónimos aragoneses Huesca y Jaca) de la que nació nada menos que el mítico Argantonio. Aquel Arrhagonio, en el año 4890 de la creación o 618 antes de Cristo, fundó una ciudad a las faldas de los Pirineos a la que puso el nombre de su esposa (Jaca) y a los habitantes y al río que por allí fluía los llamó, en recuerdo suyo, Arrhagones.

Ya sé -comenta maliciosamente Mayáns- quáles fueron las armas o blasones del rey Osco, i de los que le sucedieron en el reino, ... el fundador de Huesca y de Jaca, las verdaderas etimologías destas ciudades, del río Aragón, i por consiguiente de los aragoneses, cuyo nombre decía don Antonio Agustín que ni aún era del tiempo de $\operatorname{los} \operatorname{godos}^{27}$.

Su Censura es, ciertamente, un modelo de aplicación a los estudios históricos del método crítico por el que tanto suspiró Mayáns a lo largo de su vida. Y en ella, fiel a sus principios metodológicos, aduce todo tipo de pruebas contundentes: históricas, literarias y hasta lingüísticas. Por lo que puede afirmar que:

No sólo es contrario este Chronicón a las Divinas Escrituras, i a la tradición de todo el género humano, sino también a la mithología; porque teniendo ésta ordenadas con verosimilitud las genealogías de los falsos dioses i héroes, el Chronicón las con-

26. Mayáns y Siscar, G., Obras Completas I: Historia, ed. de A. Mestre, Valencia, 1983, p. 283.

27. Mayáns y Siscar, G., Obras Completas I: Historia, ed. de A. Mestre, Valencia, 1983, p. 284. 
funde de manera que trastorna las personas i los tiempos ... i si hemos de darle fe, ya se pueden borrar las obras de Homero, la Theogonía de Hesíodo, las Transformaciones de Ovidio, i por decirlo de una vez, toda la mithología ${ }^{28}$.

Y concluye Mayáns con palabras tajantes:

Mi parecer es que la España Primitiva, impressa en nombre del dotor don Francisco Javier Manuel de la Huerta i Vega, es un disimulado comentario del Chronicón que fingió don Josef Pellicer, atribuyéndolo a Pedro insigne orador i Maestro de Oratoria en la ciudad de Zaragoza. Este Chronicón es fingido, sin que en esto pueda tener duda cualquier hombre de juicio regular i de mediana literatura. Contiene ficciones que son contrarias a las verdades divinas, a las que se incluyen debajo de la misteriosa ficción de la mithología, a las de los historiadores más clásicos, i a la persuasión de todas las naciones más racionales. Confunde lo sagrado con lo profano. Pervierte la chronología de todas las historias antiguas; i en suma, es una fábula indecorosa, i opuesta a las verdaderas glorias de España ... I la primera acción literaria, que públicamente se ve en la Academia de la Historia, es la defensa de un libro que, debajo del título de España Pimitiva, nos representa una España fabulosa, fantástica i ridícula.

La crítica histórica entraña una desmitificación. Y Gregorio Mayáns, el Néstor de las letras españolas, como le llamó Menéndez Pelayo, no aceptó los mitos históricos coetáneos y puso todo su empeño en desmontar la historia mítica española, legada y ampliada por los falsos cronicones. Pero quienes detentaban el poder, o los intelectuales que presionaban sobre el Gobierno, no siguieron el razonamiento crítico hasta sus últimas consecuencias. Censuraron el mito hasta donde les interesó, pero utilizaron las armas de la superstición desde el momento que les convino. Cuando la crítica histórica atacó esos intereses, adoptaron una fácil solución: acusar de antiespañol a quien censuraba los criterios más o menos oficiales (Mestre, Despotismo 136).

Sólo así podemos entender tantos fracasos y frustraciones del reformismo dieciochesco y que la Corte borbónica rechace personajes -Mayáns, Burriel o Jovellanos- que, por su capacidad e inteligencia, hubieran potenciado las corrientes modernas del pensamiento y de la ciencia. Los equipos ministeriales apoyaron los mitos históricos antes que la crítica; persiguen a Mayáns por haber negado la autenticidad de los falsos cronicones o haber combatido la superstición de los plomos del Sacromonte ${ }^{29}$, mientras defienden la España Primitiva de De la Huerta y Vega por

28. Mayáns y Siscar, G., Obras Completas I: Historia, ed. de A. Mestre, Valencia, 1983, p. 272.

29. A finales del siglo XVI aparecieron en la Alcazaba de Granada unas planchas de plomo, pretendidamente del siglo I, que confirmaba la existencia de los primeros mártires del tiempo de Nerón. La ficción fue apoyada por el arzobispo Pedro de Castro y su autenticidad era todavía defendida en el siglo XVIII. 
el apoyo que le prestaron las Reales Academias de la Lengua y de la Historia; o favorecen la obra de Flórez, menos crítico que Mayáns, porque es el apasionado defensor de las glorias nacionales entre las que se cuentan las tradiciones jacobeas con el origen apostólico de la cristiandad hispánica (Mestre, Despotismo 164-5).

En el fondo se ventilaba la necesidad de estudiar el pasado con metodología científica. Frente a las leyendas y falsedades históricas, Mayáns proponía el estudio de la historia basado en documentos y con sentido crítico. El drama, tantas veces repetido, radica en que el problema científico se resuelve como una cuestión personal y sólo tardíamente la historia crítica, tal como la concibieron los ilustrados, logrará que la verdad se imponga sobre los intereses políticos y sociales ${ }^{30}$.

\section{Bibliografía}

ALLEN, D. C., Mysteriously Meant. The Rediscovery of Pagan Symbolism and Allegorical Interpretation in the Renaissance. Baltimore: John Hopkins University Press. 1970.

ÁLVAREZ BARRIENTOS, J. y MESTRE SANCHÍS, A., "La nueva mentalidad científica. El ensayo y la ciencia literaria", en CARNERO, G. (coord.), Historia de la literatura española. Siglo XVIII (I), Madrid. 1995, pp. 50-135.

ASHER, R.E., National Myths in Renaissance France: Francus, Samothes and the Druids, Edimburgh: Edimburgh U.P. 1993.

CABALLERO LÓPEZ, J.A., "El mito en las Historias de la España primitiva", Excerpta Philologica 7-8 (1997-1998), pp. 83-99.

CABALLERO LÓPEZ, J.A., "Desde el mito a la historia", en De la Iglesia, José I. (coord.), Memoria, mito y realidad en la historia medieval. Logroño: Instituto de Estudios Riojanos. 2003, pp. 33-60.

CABALLERO LÓPEZ, J.A., "El 'Beroso' de Annio de Viterbo y su presencia en las Historias de España”, Beroso. Revista de investigación y reflexión histórica sobre la Antigüedad 11-12 (2004), pp. 81-128.

CARO BAROJA, J., "La 'realeza' y los reyes en la España antigua", en Estudios sobre la España Antigua (Cuadernos de la Fundación Pastor, nº 17), Madrid. 1971, pp. 51-159.

CARO BAROJA, J., Las falsificaciones de la historia. Barcelona: Seix Barral. 1992.

30. Para el seguimiento de este proceso véase Mestre, Mayáns y la España de la Ilustración; Rey Castelao, La historiografía y Stiffoni, Verità. 
CODOÑER, C., "Las Crónicas latinas del siglo IV", en Los géneros literarios. Actes del VII Simposi d'Estudis Clàssics (21-24 de març de 1983), Bellaterra. 1985, pp. 121-140.

ESTÉVEZ SOLA, J.A., "Algo más sobre los orígenes míticos de Hispania”, Habis 24, 1993, 207-217.

ESTÉVEZ SOLA, J.A., "Aproximación a los orígenes míticos de Hispania”, Habis 21, 1990, 139-152.

FERNÁNDEZ-ORDÓÑEZ, I., Las Estorias de Alfonso X. Madrid: Istmo. 1992.

KNAPP, R.C., "La via heraclea en el Occidente: mito, arqueología, propaganda, historia", Emerita 44, 1986, pp. 103-122.

LIDA DE MALKIEL, MR., "Túbal, primer poblador de España”, Ábaco 3, 1970, pp. 11-48.

MAYÁNS Y SISCAR, G., Obras Completas I: Historia, Valencia: ed. de A. Mestre, 1983.

MESTRE, A., "La historiografía española del siglo XVIII", en Carlos III y su siglo, vol. I, Madrid: Universidad Complutense. 1990, pp. 21-60.

MESTRE, A., Mayáns y la España de la Ilustración. Madrid: Espasa-Calpe. 1990.

MESTRE, A., "Mayáns, historiador", en Mayáns y Siscar, G., Obras Completas I: Historia, Valencia: ed. de A. Mestre, 1983, pp. 21-31.

MESTRE, A., Despotismo e ilustración en España. Barcelona: Ariel. 1976.

MESTRE, A., Historia, fueros y actitudes políticas. Mayáns y la historiografía del XVIII. Valencia: Universidad de Valencia. 1970.

PÉREZ VILATELA, L., "La onomástica de los apócrifos reyes de España de Annio de Viterbo y su influencia", en José Ma Maestre y J. Pascual (coord.), Humanismo y pervivencia del mundo clásico. I. 2, Cádiz, 1993, pp. 807-819.

REY CASTELAO, O., La historiografía del voto de Santiago. Santiago de Compostela: Universidad de Santiago de Compostela. 1985.

SEZNEC, J., Los Dioses de la Antigüedad. Madrid: Taurus. 1983.

STIFFONI, G., Verità della storia e ragione del potere nella Spagna del primo Settecento. Milán: Franco Angeli. 1989.

TATE, R.B., Ensayos sobre la Historiografía Peninsular del siglo XV. Madrid: Gredos. 1970. 